Brit. J. prev. soc. Med. (1955), 9, 89-96

\title{
FERTILITY AND REPRODUCTIVE HISTORY OF MOTHERS OF MONGOLOID DEFECTIVES
}

\author{
BY \\ ALWYN SMITH AND R. G. RECORD \\ From the Department of Social Medicine, University of Birmingham
}

In a previous communication (Smith and Record, 1955) it was observed that there appeared to be an association between mongolism and primogeniture which invites investigation of the fertility of mothers of mongols. Such a study is by no means new. It has been attempted by many previous workers, prompted perhaps by the observations that the risk of producing a mongol increases sharply with advancing maternal age and that fertility of women becomes impaired as age increases.

Various indices of fertility have been used. The one most easily recorded is the size of the family at the end of the reproductive period. Shuttleworth (1909) considered that families containing a mongol tended to be larger than usual, but Brousseau (1928) regarded family size as unimportant; in neither case was comparison with a control group attempted. Penrose (1949), using fraternities containing nonmongoloid mental defectives as controls, found that mean sibship size was raised in families containing mongols. This observation could easily result from the higher maternal age at which mongols are born; by controlling this variable, Jenkins (1933) showed that the mongols of Shuttleworth's and Brousseau's series came from families rather smaller than average. The matter cannot be regarded as settled, however, since the control group used by Jenkins (U.S. births in 1927) probably differed considerably from the population from which the cases were drawn. A further objection is that the cases were diagnosed some time after birth; the increased risk of infection to which members of large fraternities are exposed, and the high mortality of mongols from infectious disease, would tend to eliminate at an early age mongols born into large families.

Another measure of fertility is the pregnancy-free interval preceding birth. The view that this interval was longer than usual was first recorded by Langdon Down (1909). Although no comparison with a control group was attempted, Beidleman (1945),
Benda (1946, 1949), and Engler (1949) supported this view, but Penrose (1934) and Bleyer (1938) considered it to be unimportant. The effect of maternal age appears to have been ignored except by Jenkins (1933), who found that the mean pregnancyfree interval preceding mongol births was longer than that shown by the general population of comparable age. This result, however, cannot be unreservedly accepted in view of the unrepresentativeness of his control group.

The pregnancy-free interval before mongol births has also been compared with the interval before the birth of unaffected sibs. By this technique, Øster (1953) showed that the period preceding the mongol conception appeared to be longer. The method presents many difficulties, one of which (referred to by Record and McKeown, 1950) arises from the fact that the larger, and therefore more fertile, families are unduly represented among the normal sibs. Øster avoided this error by restricting comparison to the same birth-rank intervals, but was consequently prevented from matching for maternal age, since in each fraternity he chose unaffected sibs born before the mongol. Two sources of error were thus introduced:

(a) in general, mothers would be older, and therefore less fertile, at the birth of the mongols than at the birth of the sibs;

(b) since sibs and mongols were matched for birth rank, sibs would be drawn from larger families than the mongols with whom they were compared.

Fertility after a mongol birth has received little attention. Øster (1953) reported that the interval between the birth of a mongol and the next conception was longer than that which followed births of succeeding unaffected sibs. Since he compared mongols with sibs of the same birth rank, he was comparing mothers who may have had no more than 
one child after the mongol with those who had had at least two. Control of birth rank may make this comparison acceptable provided fraternities are complete when the data are recorded. Since part of Øster's series did not satisfy this condition, his comparison was made against a group weighted in favour of the more fertile mothers, and his result may therefore not be free from bias.

We have been unable to find in the literature any reference to fertility studies based on a comparison of mothers of mongols with a representative control group of mothers of similar age. Inaccurate results are likely if affected and controls are derived from different populations, and failure to take account of differences in maternal age is certain to be misleading. Attempts to analyse the data by comparison with unaffected sibs are equally unsatisfactory. Error may also arise if the diagnosis of mongolism is delayed until some time after birth, since the mortality of mongols from infection in infancy is high and is almost certainly related to family size.

It seemed worth while to investigate this problem by comparing a series of mongols, most of whom were diagnosed soon after birth, with a selected control group.

\section{MATERIAL}

The mongol series, consisting of 252 cases born in the years 1942-52 to mothers normally resident in Birmingham, was assembled as previously described (Record and Smith, 1955). Details of the mothers' reproductive histories were obtained by interview and are complete for 217 cases. Comparable data were not available from the original source for the control group (consisting of 1,156 births representative of all births in the city in the same period) used in the maternal age and birth rank analysis (Smith and Record, 1955), and the information required could be obtained only by interviewing mothers. The amount of field work was reduced by selecting a sample of the control group. An attempt was made to match control births according to maternal age with the 252 mongols. This attempt was not completely successful and the control sample thus selected consisted of only 216 births, of which 139 were traced and the mothers interviewed. The field work on both mongol and control groups was carried on concurrently by the same investigators. The more efficient tracing of the mothers of mongols can probably be explained by the fact that many were known to the Local Authority's Mental Deficiency Section which was able to provide up-to-date addresses, whereas the only addresses available for controls were those given at the time of birth.

\section{RESULTS}

Before attempting a detailed analysis of the data, it is necessary to determine whether the mongol and control series are comparable in respect of variables which may be expected to influence fertility. Table I shows the two series distributed according to maternal age at birth of propositi. Some discrepancy is revealed, particularly at the age group " 40 and over" where the control group is deficient. This is because births at these ages are relatively infrequent and there were not enough in the original control group to permit exact matching. It is clear that maternal age cannot be disregarded in the following analysis.

TABLE I

DISTRIBUTION OF MONGOL AND CONTROL PROPOSITI ACCORDING TO MATERNAL AGE

\begin{tabular}{|c|c|c|c|c|c|}
\hline \multirow{2}{*}{$\begin{array}{r}\text { Maternal } \\
\text { (yrs) }\end{array}$} & \multirow{2}{*}{ Age } & \multicolumn{2}{|c|}{ Mongols } & \multicolumn{2}{|c|}{ Controls } \\
\hline & & No. & Per cent. & No. & Per cent. \\
\hline $\begin{array}{l}\text { Under } 25 \\
25- \\
30-\end{array}$ & $\begin{array}{l}\ldots \\
\cdots \\
\ddot{*}\end{array}$ & $\begin{array}{l}14 \\
36 \\
40 \\
59 \\
68\end{array}$ & $\begin{array}{r}6 \cdot 5 \\
16 \cdot 6 \\
18 \cdot 4 \\
27 \cdot 2 \\
31 \cdot 3\end{array}$ & $\begin{array}{l}14 \\
21 \\
29 \\
39 \\
36\end{array}$ & $\begin{array}{l}10 \cdot 1 \\
15 \cdot 1 \\
20 \cdot 9 \\
28 \cdot 1 \\
25 \cdot 9\end{array}$ \\
\hline Total & $\ldots$ & 217 & 100 & 139 & 100 \\
\hline
\end{tabular}

Another variable which obviously influences fertility is age at marriage (Table II). A crude comparison shows that mothers of mongols married slightly later than control mothers. Since women having children relatively late in life married, in general, later than younger mothers, this result could be due to the fact that the mongol and control propositi are not exactly matched in respect of maternal age. Support for this explanation is provided by standardizing the two series in order to remove the effect of variation due to maternal age at birth of propositi; the difference between the means is almost eliminated by this technique.

TABLE II

AGE AT MARRIAGE

\begin{tabular}{|c|c|c|c|c|c|c|}
\hline \multirow{2}{*}{\multicolumn{3}{|c|}{ Age at Marriage (yrs) }} & \multicolumn{2}{|c|}{$\begin{array}{l}\text { Mothers of } \\
\text { Mongols }\end{array}$} & \multicolumn{2}{|c|}{$\begin{array}{l}\text { Mothers of } \\
\text { Controls }\end{array}$} \\
\hline & & & \multirow{2}{*}{$\begin{array}{c}\text { No. } \\
33 \\
88 \\
56 \\
21 \\
15\end{array}$} & \multirow{2}{*}{$\begin{array}{r}\begin{array}{r}\text { Per } \\
\text { cent. }\end{array} \\
15 \cdot 5 \\
41 \cdot 3 \\
26.3 \\
9.9 \\
7.0\end{array}$} & \multirow{2}{*}{$\begin{array}{r}\text { No. } \\
22 \\
63 \\
35 \\
12 \\
4 \\
\end{array}$} & \multirow{2}{*}{$\begin{array}{r}\text { Per } \\
\text { cent. } \\
16.2 \\
46.3 \\
25.7 \\
8.8 \\
2.9\end{array}$} \\
\hline $\begin{array}{ll}\text { Under } 20 & \ldots \\
20-\ldots & \ldots \\
25- & \ldots \\
30- & \ldots \\
35 \text { and over }\end{array}$ & $\begin{array}{l}\ldots \\
\cdots \\
\cdots\end{array}$ & $\begin{array}{l}\ddot{0} \\
\ddot{0} \\
\ddot{*}\end{array}$ & & & & \\
\hline Total . & $\cdots$ & $\ldots$ & 213 & 100 & 136 & 100 \\
\hline Mean Age (C & e). & .. & \multicolumn{2}{|c|}{$24 \cdot 54$} & \multicolumn{2}{|c|}{$23 \cdot 82$} \\
\hline Difference .. & $\cdots$ & .. & \multicolumn{4}{|c|}{$0.72 \pm 0.54$} \\
\hline \multicolumn{3}{|c|}{ Mean Age (Standardized)* } & \multicolumn{2}{|c|}{$24 \cdot 34$} & \multicolumn{2}{|c|}{$24 \cdot 13$} \\
\hline Difference .. & . & .. & & & & \\
\hline
\end{tabular}

Four mothers of mongols and two control mothers were unmarriod. Age at marriage was not recorded for one control mother.

* The mongol and control series are standardized to the same distribution of maternal age at birth of propositi. 
FERTILITY BEFORE BIRTH OF A MONGOL.-An index of the mother's fertility during the period between marriage and the conception resulting in the propositus is derived from the number of pregnancies occurring within the period. This value is partly dependent on age at marriage and partly on duration of marriage. It has been shown (Table II) that variation arising from differences in age at marriage can be removed by standardizing the affected and control groups to the same distribution by maternal age at birth of propositi. This procedure also removes the effect of differences between the two groups in duration of marriage, since if both age at marriage and age at birth of propositi are fixed, the two groups must be comparable in respect of duration of marriage. (We satisfied ourselves that this was so by calculating the mean duration of marriage for the two standardized series; values of 10.40 and 10.75 years were obtained for mothers of mongols and controls respectively.)

Restricting attention to pregnancies which proceed to a viable stage (at least 28 weeks), we note (Table III) that in general, the birth of a mongol is preceded by fewer pregnancies than that of the control propositi of comparable maternal age (standardized means are 2.07 and 2.31 respectively). This result is, of course, consistent with the primogeniture effect previously observed (Smith and Record, 1955). Since mothers of mongols and of controls are comparable in respect of age at marriage, it seems likely that the relatively increased incidence of mongolism among first born is due to impairment of fertility at some time before the mongol conception. It should be noted, however, that fertility has here been interpreted in a demographic sense, pregnancies failing to reach a viable stage being ignored. It has often been asserted that mothers of mongols experience a higher abortion rate than other women; the present series provides support for this view, the incidence of abortions in pregnancies preceding births of mongol and control propositi being $10 \cdot 1$ and $7 \cdot 2$ per cent. respectively. After correction for differences in maternal age, the abortion rates of the two series were 10.3 and 6.7 per cent. When abortions are added to viable pregnancies and the two series standardized as before, the mean numbers of prior pregnancies are $2 \cdot 31$ and $2 \cdot 49$ respectively for mothers of mongols and controls (difference $0 \cdot 18 \pm 0 \cdot 27$ ).

It is concluded that examination of the period between marriage and a conception resulting in a mongol provides little evidence of impaired fertility. It is possible of course that a more detailed examination may reveal differences between the two groups. For example, there may be an initial period of high fertility followed by one of impaired fertility terminating with the mongol conception. In order to examine this point, pregnancy-free intervals before propositi and before their prior sibs have been calculated. The periods were measured from the termination of one pregnancy to the conception of the next. In the case of first pregnancies, the interval was measured from the time of marriage, pre-marital conceptions being exluded.

Examination of pregnancy-free intervals immediately preceding conceptions of propositi is based on 208 mothers of mongols and 137 controls (Table IV).

TABLE IV

MEAN PREGNANCY-FREE INTERVALS (MONTHS) IMMEDIATELY PRECEDING CONCEPTION OF PROPOSITI

\begin{tabular}{c|c|c|c|c|c|c}
\hline $\begin{array}{c}\text { Maternal Age } \\
\text { (yrs) at Birth of } \\
\text { Propositus }\end{array}$ & $\begin{array}{c}\text { Under } \\
25\end{array}$ & $25-$ & $30-$ & $35-$ & $\begin{array}{c}40 \text { and } \\
\text { over }\end{array}$ & $\begin{array}{c}\text { All } \\
\text { Ages }\end{array}$ \\
\hline $\begin{array}{c}\text { Mothers of } \\
\text { Mongols }\end{array}$ & $\begin{array}{c}11 \cdot 6 \\
(9)\end{array}$ & $\begin{array}{c}28 \cdot 5 \\
(35)\end{array}$ & $\begin{array}{c}54 \cdot 2 \\
(39)\end{array}$ & $\begin{array}{c}65 \cdot 9 \\
(58)\end{array}$ & $\begin{array}{c}79 \cdot 0 \\
(67)\end{array}$ & $\begin{array}{c}58 \cdot 0 * \\
(208)\end{array}$ \\
\hline $\begin{array}{c}\text { Mothers of } \\
\text { Controls }\end{array}$ & $\begin{array}{c}13 \cdot 2 \\
(13)\end{array}$ & $\begin{array}{c}47 \cdot 6 \\
(21)\end{array}$ & $\begin{array}{c}52 \cdot 6 \\
(28)\end{array}$ & $\begin{array}{c}53 \cdot 0 \\
(39)\end{array}$ & $\begin{array}{c}65 \cdot 2 \\
(36)\end{array}$ & $\begin{array}{c}53 \cdot 2 * \\
(137)\end{array}$ \\
\hline
\end{tabular}

Numbers of mothers are given in brackets.

Nine mongols and two control propositi resulting from pre-marital conceptions have been excluded.

* Standardized to the maternal age distribution of the combined series.

TABLE III

PREGNANCIES PRECEDING CONCEPTION OF PROPOSITI

\begin{tabular}{|c|c|c|c|c|c|c|c|c|c|c|c|c|}
\hline \multirow{2}{*}{$\begin{array}{c}\text { Maternal Age (yrs) at Birth of } \\
\text { Propositus }\end{array}$} & \multicolumn{2}{|c|}{ Under 25} & \multicolumn{2}{|c|}{$25-$} & \multicolumn{2}{|c|}{$30-$} & \multicolumn{2}{|c|}{ 35- } & \multicolumn{2}{|c|}{40 and over } & \multicolumn{2}{|c|}{ All Ages } \\
\hline & $\begin{array}{l}\text { Mon- } \\
\text { gols }\end{array}$ & $\begin{array}{l}\text { Con- } \\
\text { trols }\end{array}$ & $\begin{array}{l}\text { Mon- } \\
\text { gols }\end{array}$ & $\begin{array}{c}\text { Con- } \\
\text { trols }\end{array}$ & $\begin{array}{c}\text { Mon- } \\
\text { gols }\end{array}$ & $\begin{array}{l}\text { Con- } \\
\text { trols }\end{array}$ & $\begin{array}{l}\text { Mon- } \\
\text { gols }\end{array}$ & $\begin{array}{l}\text { Con- } \\
\text { trols }\end{array}$ & $\begin{array}{l}\text { Mon- } \\
\text { gols }\end{array}$ & $\begin{array}{l}\text { Con- } \\
\text { trols }\end{array}$ & $\begin{array}{c}\text { Mon- } \\
\text { gols }\end{array}$ & $\begin{array}{l}\text { Con- } \\
\text { trols }\end{array}$ \\
\hline $\begin{array}{l}\text { No. of Mothers } \\
\text { No. of Preceding Viable Pregnancies } \\
\text { Mean No. of Preceding Viable Preg- }\end{array}$ & $\begin{array}{r}14 \\
3\end{array}$ & $\begin{array}{r}14 \\
2\end{array}$ & $\begin{array}{l}36 \\
37\end{array}$ & $\begin{array}{l}21 \\
10\end{array}$ & $\begin{array}{l}40 \\
47\end{array}$ & $\begin{array}{l}29 \\
46\end{array}$ & $\begin{array}{r}59 \\
139\end{array}$ & $\begin{array}{r}39 \\
112\end{array}$ & $\begin{array}{r}68 \\
236\end{array}$ & $\begin{array}{r}36 \\
139\end{array}$ & $\begin{array}{l}217 \\
462\end{array}$ & $\begin{array}{l}139 \\
309\end{array}$ \\
\hline $\begin{array}{lllll}\text { nancies } & \ldots & \ldots & \ldots & \ldots\end{array}$ & 0.21 & $0 \cdot 14$ & $1 \cdot 03$ & 0.48 & $1 \cdot 17$ & $1 \cdot 59$ & $2 \cdot 36$ & $2 \cdot 87$ & $3 \cdot 47$ & $3 \cdot 86$ & $2 \cdot 07^{*}$ & $2 \cdot 31^{*}$ \\
\hline No. of Preceding Abortions .. & $\mathbf{0}$ & 2 & 4 & $\mathbf{0}$ & 10 & 4 & 16 & 10 & 22 & 8 & 52 & 24 \\
\hline $\begin{array}{ccccc}\text { Mean No. of } & \text { All } & \text { Preceding Preg- } \\
\text { nancies } & \ldots & \ldots & \ldots & \ldots\end{array}$ & $0 \cdot 21$ & $0 \cdot 29$ & $1 \cdot 14$ & 0.48 & $1 \cdot 42$ & $1 \cdot 72$ & $2 \cdot 63$ & $3 \cdot 13$ & $3 \cdot 79$ & $4 \cdot 08$ & $2 \cdot 31 *$ & $2 \cdot 49 *$ \\
\hline
\end{tabular}

* Standardized to the maternal age distribution of the combined series 
Standardization of the means to the same maternal age distribution gives values of 58.0 and 53.2 (difference $4.8 \pm 4.9$ months). In this analysis, abortions have been ignored and fallow periods have been calculated from the termination of the preceding viable pregnancy. If abortions are recognized and the term "pregnancy-free interval" interpreted strictly, the means are reduced $(53.8$ and $49 \cdot 3$ months), but the difference $(4 \cdot 5$ is not much affected. We conclude that if, as has frequently beep asserted, mongols are conceived after a period of infertility, a much larger series than the present one would be required to establish the point.

We now consider fallow periods preceding pregnancies which occurred before that which resulted in a propositus; the number of pregnancies for consideration in each sibship varies from 1 to 12 . In order to prevent undue representation of the more fertile mothers, the mean fallow period preceding sibs born before propositi was calculated separately for each fraternity. The means of the mean fallow periods were then determined (Table V).

TABLE V

MEAN PREGNANCY-FREE INTERVALS (MONTHS) PRECEDING SIBS BORN BEFORE PROPOSITUS

\begin{tabular}{c|c|c|c|c|c|c}
\hline $\begin{array}{c}\text { Maternal Age } \\
\text { (yrs) at Birth of } \\
\text { Propositus }\end{array}$ & Under & $25-$ & $30-$ & $35-$ & $\begin{array}{c}40 \text { and } \\
\text { over }\end{array}$ & $\begin{array}{c}\text { All } \\
\text { Ages }\end{array}$ \\
\hline $\begin{array}{c}\text { Mothers of } \\
\text { Mongols }\end{array}$ & $\begin{array}{c}7 \cdot 3 \\
(3)\end{array}$ & $\begin{array}{c}19 \cdot 6 \\
(17)\end{array}$ & $\begin{array}{c}29 \cdot 6 \\
(22)\end{array}$ & $\begin{array}{c}29 \cdot 3 \\
(41)\end{array}$ & $\begin{array}{c}32 \cdot 8 \\
(61)\end{array}$ & $\begin{array}{l}29 \cdot 3^{*} \\
(144)\end{array}$ \\
\hline $\begin{array}{c}\text { Mothers of } \\
\text { Controls }\end{array}$ & $\begin{array}{c}4 \cdot 5 \\
(2)\end{array}$ & $\begin{array}{c}17 \cdot 3 \\
(7)\end{array}$ & $\begin{array}{c}31 \cdot 8 \\
(22)\end{array}$ & $\begin{array}{c}32 \cdot 6 \\
(27)\end{array}$ & $\begin{array}{c}38 \cdot 5 \\
(34)\end{array}$ & $\begin{array}{c}32 \cdot 7^{*} \\
(92)\end{array}$ \\
\hline
\end{tabular}

Numbers of mothers are given in brackets.

Twelve mothers of mongols and eleven controls were unmarried at the commencement of first pregnancy and have been excluded.

* Standardized to the maternal age distribution of the combined series.

Standardization of the two series to the same distribution by maternal age at birth of propositi gives means of $29 \cdot 3$ and $32 \cdot 7$ months (difference $3 \cdot 4 \pm 2 \cdot 8$ ) for mothers of mongols and controls respectively. If all pregnancies, including those terminating in abortion, are taken into account, the means are reduced to $27 \cdot 1$ and 32.0 months. The difference ( 4.9 months) is increased, but is not large enough to provide firm evidence of a difference in fertility.

FERTILITY AFTER BIRTH OF A MONGOL.-The interval between the birth of a propositus and the date of the field inquiry ranged from less than one year to nearly 12 years. The length of this period obviously affects the number of subsequent sibs. Its effect on their preceding fallow periods is also important; its restriction would result in inadequate representation of the longer fallow periods. It is shown (Table VI) that the mongol and control series are not comparable in respect of year of birth of propositi, probably because of incomplete ascertainment of mongols in the earlier years. It is necessary, therefore, to standardize for this variable, as well as for the age of the mother at the birth of the propositus.

TABLE VI

YEAR OF BIRTH OF PROPOSITUS

\begin{tabular}{|c|c|c|c|c|c|}
\hline \multirow{2}{*}{\multicolumn{2}{|c|}{ Years }} & \multicolumn{2}{|c|}{ Mongols } & \multicolumn{2}{|c|}{ Controls } \\
\hline & & No. & Per cent. & No. & Per cent. \\
\hline $\begin{array}{l}1942-44 \ldots \\
1945-48 \\
1949-52\end{array}$ & $\begin{array}{l}\cdots \\
\cdots\end{array}$ & $\begin{array}{l}62 \\
78 \\
77\end{array}$ & $\begin{array}{l}28 \cdot 6 \\
35 \cdot 9 \\
35 \cdot 5\end{array}$ & $\begin{array}{l}48 \\
49 \\
42\end{array}$ & $\begin{array}{l}34 \cdot 5 \\
35 \cdot 3 \\
30 \cdot 2\end{array}$ \\
\hline Total .. & .. & 217 & 100 & 139 & 100 \\
\hline
\end{tabular}

The number of subsequent pregnancies is examined in Table VII. When the two series are made exactly comparable in respect of year of birth of propositi and maternal age, mean values of 0.36 and 0.34 viable pregnancies per mother are obtained for mothers of mongols and of controls respectively. The abortion rate is considerably higher after mongol than after control births $(14.0$ and 3.8 per 100 conceptions respectively). When abortions are included, the mean numbers of pregnancies for mothers of mongols and controls are 0.43 and 0.35 (difference $0.08 \pm 0.08$ ).

TABLE VII

PREGNANCIES FOLLOWING BIRTHS OF PROPOSITI

\begin{tabular}{|c|c|c|c|c|c|c|c|c|c|c|c|c|}
\hline \multirow{2}{*}{$\begin{array}{l}\text { Maternal Age (yrs) at Birth of } \\
\text { Propositus }\end{array}$} & \multicolumn{2}{|c|}{ Under 25} & \multicolumn{2}{|c|}{ 25- } & \multicolumn{2}{|c|}{$30-$} & \multicolumn{2}{|c|}{ 35- } & \multicolumn{2}{|c|}{40 and over } & \multicolumn{2}{|c|}{ All Ages } \\
\hline & $\begin{array}{l}\text { Mon- } \\
\text { gols }\end{array}$ & $\begin{array}{l}\text { Con- } \\
\text { trols }\end{array}$ & $\begin{array}{l}\text { Mon- } \\
\text { gols }\end{array}$ & $\begin{array}{l}\text { Con- } \\
\text { trols }\end{array}$ & $\begin{array}{l}\text { Mon- } \\
\text { gols }\end{array}$ & $\begin{array}{l}\text { Con- } \\
\text { trols }\end{array}$ & $\begin{array}{l}\text { Mon- } \\
\text { gols }\end{array}$ & $\begin{array}{l}\text { Con- } \\
\text { trols }\end{array}$ & $\begin{array}{l}\text { Mon- } \\
\text { gols }\end{array}$ & $\begin{array}{l}\text { Con- } \\
\text { trols }\end{array}$ & $\begin{array}{l}\text { Mon- } \\
\text { gols }\end{array}$ & $\begin{array}{l}\text { Con- } \\
\text { trols }\end{array}$ \\
\hline 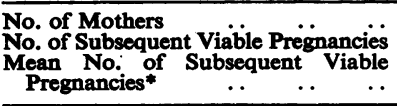 & $\begin{array}{r}14 \\
12 \\
0 \cdot 79\end{array}$ & $\begin{array}{r}14 \\
10 \\
0 \cdot 71\end{array}$ & $\begin{array}{r}36 \\
20 \\
0.62\end{array}$ & $\begin{array}{r}21 \\
9 \\
0 \cdot 33\end{array}$ & $\begin{array}{r}40 \\
20 \\
0 \cdot 50\end{array}$ & $\begin{array}{r}29 \\
16 \\
0 \cdot 55\end{array}$ & $\begin{array}{r}59 \\
18 \\
0 \cdot 33\end{array}$ & $\begin{array}{r}39 \\
14 \\
0 \cdot 39\end{array}$ & $\begin{array}{r}68 \\
4 \\
0.06\end{array}$ & $\begin{array}{r}36 \\
2 \\
0.06\end{array}$ & $\begin{array}{r}217 \\
74 \\
0 \cdot 36 t\end{array}$ & $\begin{array}{r}139 \\
51 \\
0 \cdot 34 t\end{array}$ \\
\hline No. of Subsequent Abortions & 1 & 1 & 4 & $\mathbf{0}$ & 3 & $\mathbf{0}$ & 2 & 1 & 2 & $\mathbf{0}$ & 12 & 2 \\
\hline $\begin{array}{ccccc}\text { Mean No. of All Subsequent Preg- } \\
\text { nancies* } \\
\text {. } & \ldots & \ldots & \ldots\end{array}$ & 0.89 & $0 \cdot 78$ & $0 \cdot 76$ & $\mathbf{0} \cdot \mathbf{3 3}$ & $0 \cdot 57$ & $0 \cdot 55$ & $\mathbf{0} \cdot \mathbf{3 7}$ & 0.41 & 0.09 & 0.06 & $0.43 t$ & $0 \cdot 35 t$ \\
\hline
\end{tabular}

* Standardized to the distribution by year of birth of the combined series.

+ Standardized to the distribution by year of birth and by maternal age of the combined series. 
Of more interest, perhaps, is the duration of the pregnancy-free interval immediately following the mongol birth. In the mongol series, 62 propositi were followed by at least one conception within the period; in three cases precise dates were unknown. Corresponding figures for controls were 36 and two. After standardization for year of birth of propositus and for maternal age (Table VIII), the mean intervals between the birth of the propositi and the next conception were 21.6 months for the mongol fraternities and 21.4 months for the controls.

It is concluded that women who have given birth to mongols show no evidence of subsequent impairment of fertility.

\section{TABLE VIII}

MEAN PREGNANCY-FREE INTERVALS* BETWEEN BIRTHS OF PROPOSITI AND IMMEDIATELY SUCCEEDING CONCEPTIONS

\begin{tabular}{|c|c|c|c|c|c|}
\hline $\begin{array}{l}\text { Maternal Age (yrs) } \\
\text { at Birth of } \\
\text { Propositus }\end{array}$ & Under & 25 & $30-$ & $\begin{array}{l}35 \text { and } \\
\text { over }\end{array}$ & $\begin{array}{c}\text { All } \\
\text { Ages }\end{array}$ \\
\hline $\begin{array}{l}\text { Mothers of } \\
\text { Mongols }\end{array}$ & $\begin{array}{c}20 \cdot 0 \\
(8)\end{array}$ & $\begin{array}{l}24 \cdot 5 \\
(13)\end{array}$ & $\begin{array}{l}25 \cdot 0 \\
(17)\end{array}$ & $\begin{array}{l}17 \cdot 3 \\
(21)\end{array}$ & $\begin{array}{l}21 \cdot 6 t \\
(59)\end{array}$ \\
\hline Mothers of & $\begin{array}{l}25 \cdot 0 \\
\text { (6) }\end{array}$ & $\begin{array}{l}21 \cdot 6 \\
\text { (6) }\end{array}$ & $\begin{array}{l}21 \cdot 9 \\
(12)\end{array}$ & $\begin{array}{l}19 \cdot 1 \\
(10)\end{array}$ & $\begin{array}{l}21 \cdot 4 t \\
(34)\end{array}$ \\
\hline
\end{tabular}

Numbers of mothers are given in brackets.

- Standardized to the distribution by year of birth of the combined series.

t Standardized to the distribution by year of birth and by maternal age of the combined series.

\section{Other Aspects of Reproductive Function}

Having considered reproductive performance as measured by the frequency with which conceptions occur, we turn now to the examination of other aspects of reproductive function. The relevant literature is most conveniently discussed in relation to the results of the present investigation.

Age AT Menarche.-Age at onset of menstruation in mothers of mongols can be determined only by retrospective inquiry. The objections to this method are illustrated by an apparent correlation between age at menarche and age at birth of propositi (Table IX). It is probable that women tend to advance the date of menarche as they get older, and the impression that the menarche is delayed in women who later have mongols (Geyer, 1937; Doxiades and Portius, 1938) may have arisen in this way. The data support the view of Schröder (1938) that these women do not differ from other women in age at menarche.
TABLE IX

MEAN AGE AT MENARCHE

\begin{tabular}{|c|c|c|c|}
\hline \multicolumn{2}{|c|}{$\begin{array}{c}\text { Maternal Age (yrs) } \\
\text { at Birth of } \\
\text { Propositi }\end{array}$} & \multirow{2}{*}{$\begin{array}{c}\text { Mothers of Mongols } \\
13 \cdot 15(14) \\
13.92(36) \\
13 \cdot 72(39) \\
14 \cdot 02(57) \\
14 \cdot 80(66)\end{array}$} & \multirow{2}{*}{$\begin{array}{c}\text { Mothers of Controls } \\
13 \cdot 37(13) \\
13 \cdot 25(21) \\
13 \cdot 33(27) \\
14 \cdot 22(28) \\
14 \cdot 28(36)\end{array}$} \\
\hline $\begin{array}{l}\text { Under } 25 \ldots \\
25-\ldots \\
30-\ldots \\
35-\ldots \\
40 \text { and over }\end{array}$ & $\begin{array}{l}\ddot{ } \\
\ddot{*} \\
\cdots\end{array}$ & & \\
\hline Mean Age* & $\ldots$ & $14 \cdot 11(212)$ & $13 \cdot 84(135)$ \\
\hline Difference & - & \multicolumn{2}{|c|}{$0.27 \pm 0.20$} \\
\hline
\end{tabular}

Numbers of mothers are shown in brackets. Five mothers of mongols and four mothers of controls did not remember age at menarche.

* Standardized to the distribution by age at birth of propositi of the combined series.

Menstrual History.-Although strictly reliable data can be obtained only from records kept for the purpose of inquiry, it was felt that interrogation of the mother as to her usual cycle length and duration of flow might give results which could be used for the present purpose. For mothers of mongols and controls respectively, mean cycle lengths were $28 \cdot 86$ and 29.50 days (difference: $0.64 \pm 0.79$ ), and mean duration of flow $5 \cdot 16$ and $5 \cdot 01$ days (difference: $0 \cdot 15 \pm 0 \cdot 18$ ). These results do not support the view that menstrual irregularities are of aetiological importance (Geyer, 1937; Doxiades and Portius, 1938).

Duration of post-partum amenorrhoea following birth of mongols was slightly shorter than that following the birth of control propositi (means 3.07 and $3 \cdot 12$ months respectively). The difference can be accounted for by the shorter duration of lactation after mongol births, due either to their early death or to difficulty in feeding; standardization of the two groups for this variable reverses the difference, which is not, however, sufficiently marked to invite comment (means: $3 \cdot 10$ and $2 \cdot 71$ months).

ONSET OF MENOPAUSE.-Periods of amenorrhoea and flushings were accepted as evidence of the menopause. One or both symptoms were experienced either before or within a year after the birth of the propositus by nineteen mothers of mongols and eight mothers of controls, all of whom were over 35 years old. Table X (overleaf) shows that mothers of mongols and mothers of controls who were in this age group at the birth of a propositus were well matched. This variable can therefore be ignored in examination of onset of the menopause. The incidence of menopausal symptoms was $15 \cdot 6$ per cent. (nineteen in 122 women) for mothers 
of mongols and $11 \cdot 3$ per cent. (eight in 71) for mothers of controls (difference: $4 \cdot 3 \pm 5 \cdot 2$ per cent.) There is little difference between the two groups in respect of the mean ages of women who experienced menopausal symptoms $(0.7 \pm 1 \cdot 2$ years). The numbers are admittedly small, but a delayed menopause does not appear to be characteristic of women who have given birth to mongols. The view of Øster (1953) that the menopause occurs later in them than in the general population of women is not, of course, inconsistent with this conclusion. Any group of women identified by birth of a child in the later years of the reproductive period would probably show late onset of the menopause.

\section{TABLE X}

INCIDENCE OF MENOPAUSAL SYMPTOMS BEFORE OR LESS THAN A YEAR AFTER BIRTH OF PROPOSITI

\begin{tabular}{|c|c|c|c|c|c|c|}
\hline \multirow{2}{*}{\multicolumn{3}{|c|}{$\begin{array}{l}\text { Age (yrs) at Birth } \\
\text { of Propositi }\end{array}$}} & \multicolumn{2}{|c|}{ Mothers of Mongols } & \multicolumn{2}{|c|}{ Mothers of Controls } \\
\hline & & & No. & $\begin{array}{l}\text { No. who had } \\
\text { Menopausal } \\
\text { Symptoms }\end{array}$ & No. & $\begin{array}{l}\text { No. who had } \\
\text { Menopausal } \\
\text { Symptoms }\end{array}$ \\
\hline \multicolumn{3}{|c|}{$\begin{array}{l}36 \\
37 \\
38 \\
39 \\
40 \\
41 \\
42 \\
43 \\
44 \\
45 \\
46 \\
47 \\
48\end{array}$} & $\begin{array}{r}13 \\
14 \\
17 \\
10 \\
18 \\
18 \\
11 \\
10 \\
4 \\
4 \\
2 \\
1 \\
0\end{array}$ & $\begin{array}{l}1 \\
1 \\
3 \\
2 \\
2 \\
2 \\
2 \\
3 \\
1 \\
2 \\
2 \\
0 \\
2 \\
0 \\
0\end{array}$ & $\begin{array}{r}8 \\
8 \\
8 \\
11 \\
6 \\
14 \\
7 \\
4 \\
2 \\
0 \\
1 \\
1 \\
1\end{array}$ & $\begin{array}{l}\mathbf{0} \\
\mathbf{0} \\
\mathbf{1} \\
\mathbf{1} \\
\mathbf{0} \\
\mathbf{3} \\
\mathbf{2} \\
\mathbf{0} \\
\mathbf{0} \\
0 \\
0 \\
0 \\
1\end{array}$ \\
\hline Total & .. & .. & 122 & 19 & 71 & 8 \\
\hline Mean & ge & .. & 39.9 & $40 \cdot 8(a)$ & $39 \cdot 8$ & $441 \cdot 5(b)$ \\
\hline \multicolumn{3}{|c|}{ Difference $(b)-(a)$} & \multicolumn{4}{|c|}{$0.7 \pm 1 \cdot 2$} \\
\hline
\end{tabular}

ABORTION RATES.- It has frequently been stated that mothers of mongols experience an abnormally high abortion rate with their other pregnancies (Murphy, 1936; Benda, Dayton, and Prouty, 1943; Beidleman, 1945; Engler, 1949; Benda, 1949). This view was not supported by Schröder (1938) or Penrose (1949). Two workers (Murphy, 1936; Penrose, 1949) who attempted comparison with a control group (consisting in each case of mothers of non-mongoloid defectives) obtained conflicting results, and the matter cannot be regarded as settled.

The subject has already received brief consideration in the discussion of fertility, where it was noted that mothers of mongols had a higher abortion rate than mothers of the control group. Before the data are examined in more detail it is desirable to ascertain whether the two groups are comparable in respect of number of conceptions.
It is shown (Table XI) that they are well matched, both in distribution according to number of conceptions and in the mean number of conceptions per woman.

TABLE XI

NUMBER OF CONCEPTIONS OF MOTHERS OF MONGOLS AND OF CONTROLS

\begin{tabular}{|c|c|c|c|c|}
\hline \multirow{2}{*}{$\begin{array}{l}\text { No. of } \\
\text { Conceptions* } \\
\text { per Mother }\end{array}$} & \multicolumn{2}{|c|}{ Mothers of Mongols } & \multicolumn{2}{|c|}{ Mothers of Controls } \\
\hline & No. & Per cent. & No. & Per cent. \\
\hline $\begin{array}{l}0 \\
1 \\
2 \\
3 \text { or } 4 \\
5 \text { or } 6 \\
7 \text { or more }\end{array}$ & $\begin{array}{l}30 \\
53 \\
40 \\
51 \\
22 \\
21\end{array}$ & $\begin{array}{r}13 \cdot 8 \\
24 \cdot 4 \\
18 \cdot 4 \\
23 \cdot 5 \\
10 \cdot 1 \\
9 \cdot 7\end{array}$ & $\begin{array}{l}18 \\
39 \\
25 \\
32 \\
11 \\
14\end{array}$ & $\begin{array}{r}12 \cdot 9 \\
28 \cdot 1 \\
18 \cdot 0 \\
23 \cdot 0 \\
7 \cdot 9 \\
10 \cdot 1\end{array}$ \\
\hline Total & 217 & 100 & 139 & 100 \\
\hline $\begin{array}{l}\text { Mean No. of } \\
\text { Conceptions }\end{array}$ & \multicolumn{2}{|c|}{$2 \cdot 76$} & \multicolumn{2}{|c|}{$2 \cdot 78$} \\
\hline Difference & \multicolumn{4}{|c|}{$0.02 \pm 0.27$} \\
\hline
\end{tabular}

* The conception which resulted in birth of a propositus is excluded.

Mothers of mongols had 600 conceptions, of which $64(10.7$ per cent.) were followed by abortion; control mothers had 386 conceptions with 26 (6.7 per cent.) abortions. (Pregnancies resulting in propositi are excluded.) The figures are not materially altered by standardization for maternal age. Some of the difference $(4 \cdot 0 \pm 1.9)$ was due to a few women having had repeated abortions (Table XII). Nearly half the abortions experienced by mothers of mongols occurred in women who had more than one abortion; the corresponding proportion for control mothers was less than one-quarter.

TABLE XII

INCIDENCE OF ABORTIONS

\begin{tabular}{|c|c|c|c|c|c|c|}
\hline \multirow[b]{2}{*}{$\begin{array}{c}\text { No. of } \\
\text { Abortions } \\
\text { per } \\
\text { Mother }\end{array}$} & \multicolumn{3}{|c|}{ Mothers of Mongols* } & \multicolumn{3}{|c|}{ Mothers of Controls* } \\
\hline & $\begin{array}{c}\text { No. of } \\
\text { Mothers }\end{array}$ & $\begin{array}{l}\text { Per } \\
\text { cent. }\end{array}$ & $\begin{array}{l}\text { Total No. } \\
\text { of } \\
\text { Abortions }\end{array}$ & $\begin{array}{c}\text { No. of } \\
\text { Mothers }\end{array}$ & $\begin{array}{c}\text { Per } \\
\text { cent. }\end{array}$ & $\begin{array}{l}\text { Total No. } \\
\text { of } \\
\text { Abortions }\end{array}$ \\
\hline $\begin{array}{l}0 \\
1 \\
2 \\
3 \\
4 \\
5\end{array}$ & $\left.\begin{array}{r}142 \\
34 \\
6 \\
3 \\
1 \\
1\end{array}\right\}$ & $\begin{array}{r}75 \cdot 9 \\
18 \cdot 2 \\
5 \cdot 9\end{array}$ & $\begin{array}{r}0 \\
34 \\
30\end{array}$ & $\left.\begin{array}{c}98 \\
20 \\
3 \\
0 \\
0 \\
0\end{array}\right\}$ & $\begin{array}{r}81 \cdot 0 \\
16 \cdot 5 \\
2 \cdot 5\end{array}$ & $\begin{array}{r}0 \\
20 \\
6\end{array}$ \\
\hline Total .. & 187 & 100 & 64 & 121 & 100 & 26 \\
\hline
\end{tabular}

* Thirty mothers of mongols and eighteen control mothers who had had no conception except that resulting in the propositus have been excluded.

We have also inquired whether abortions are more frequent in the period preceding and following the birth of propositi. The numbers are insufficient to give an unequivocal answer; but the evidence gives little support for the view that abortion is particularly likely in the pregnancy immediately before or after the propositus (Table XIII, opposite). 
TABLE XIII

INCIDENCE OF ABORTIONS ACCORDING TO PROXIMITY OF PROPOSITUS

\begin{tabular}{|c|c|c|c|c|c|c|c|c|c|c|c|}
\hline \multirow{2}{*}{. } & \multirow{2}{*}{\multicolumn{3}{|c|}{ Conceptions }} & & \multicolumn{3}{|c|}{ Mothers of Mongols } & \multicolumn{3}{|c|}{ Mothers of Controls } & \multirow[b]{2}{*}{$\begin{array}{r}\text { Difference } \\
(\text { a })-(b)\end{array}$} \\
\hline & & & & & $\begin{array}{c}\text { No. of } \\
\text { Conceptions }\end{array}$ & $\begin{array}{l}\text { No. of } \\
\text { Abortions }\end{array}$ & $\begin{array}{c}\text { Abortion } \\
\text { Rate } \\
\text { (per cent.) } \\
\text { (a) }\end{array}$ & $\begin{array}{c}\text { No. of } \\
\text { Conceptions }\end{array}$ & $\begin{array}{c}\text { No. of } \\
\text { Abortions }\end{array}$ & $\begin{array}{c}\text { Abortion } \\
\text { Rate } \\
\text { (per cent.) } \\
\text { (b) }\end{array}$ & \\
\hline $\begin{array}{l}\text { Immedi } \\
\text { Prop }\end{array}$ & & $\begin{array}{c}\text { Preceding } \\
. .\end{array}$ & or & $\begin{array}{c}\text { Succeeding } \\
. . \\
.\end{array}$ & 227 & 31 & $13 \cdot 7$ & 146 & 13 & 8.9 & $4 \cdot 8 \pm 3 \cdot 4$ \\
\hline Others & $\cdots$ & $\cdots$ & $\cdots$ & . $\quad$. & 373 & 33 & $8 \cdot 8$ & 240 & 13 & 5.4 & $3 \cdot 4 \pm 2 \cdot 2$ \\
\hline Total & .. &. & . & . & 600 & 64 & $10 \cdot 7$ & 386 & 26 & $6 \cdot 7$ & $4 \cdot 0 \pm 1 \cdot 9$ \\
\hline
\end{tabular}

Uterine Bleeding during Pregnancy.-A high incidence of bleeding during the pregnancy resulting in the mongol has been reported (Geyer, 1937; Schröder, 1938; Beidleman, 1945; Ingalls, 1947; Benda, 1949), but comparison with a control group has not been attempted. In a retrospective inquiry, accurate reporting is impossible, and in examining the data we place more reliance on a comparison between the affected and control groups than on the actual incidence. Bleeding during the first 3 months of pregnancy was reported 23 times ( 10.6 per cent.) in respect of mongols and twelve times $(8.6$ per cent.) in respect of controls (difference $2 \cdot 0 \pm 3 \cdot 2$ per cent.). The difference is even smaller after standardization for maternal age and birth rank ( 1.7 per cent.).

Gynaecological Disorders.-Pelvic disorders for which specialist advice was obtained were reported by 48 of the 217 mothers of mongols ( $22 \cdot 1$ per cent.) and by thirty of the 139 control mothers (21.6 per cent.). The difference is quite insignificant and is scarcely altered by standardization for age or year of birth of propositi. Reasons for seeking advice (Table XIV) should be accepted with reserve, since the information is based on patients' statements and was not confirmed from hospital records. No support is provided for the view of Ingalls (1947) that uterine retroflexion is of aetiological importance. The most notable feature of the Table is the

TABLE XIV

REASONS FOR GYNAECOLOGICAL CONSULTATIONS

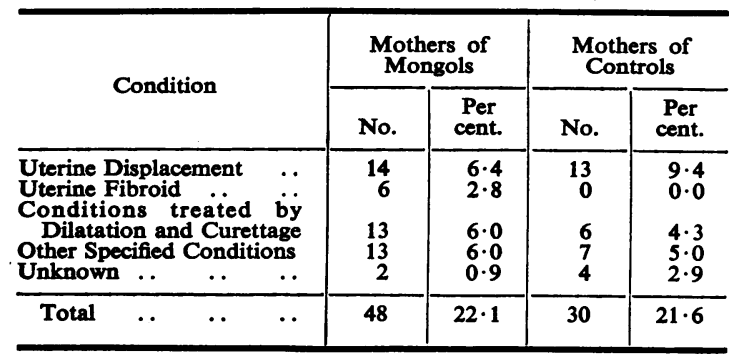

difference in incidence of uterine fibroids, but in view of the small numbers and the possibility of under-reporting of the condition by the control mothers little importance can be attached to it.

\section{Discussion}

An increase in incidence with advancing maternal age is perhaps more firmly established and more striking in mongolism than in any other condition. It has been noted consistently in reported series, and shown to be largely, though not entirely, independent of the influence of birth order. There is thus good reason to believe that the maternal environment is important in the aetiology of mongolism, and attention has not unnaturally been directed to the changes which occur in the reproductive system as age increases (decline of fertility, increased incidence of abortions, the menopause, development of fibroids and other pathological conditions). The present inquiry provides little evidence of abnormalities in the reproductive system of mothers of mongols. Since this conclusion conflicts with some previous reports, we may briefly consider possible reasons for this variation.

Some investigators have attempted to explore the reproductive history without use of a control group; this procedure is evidently unreliable unless the incidence of abnormality is very high indeed. In two reports controls were used, but they consisted of mothers of non-mongoloid mental defectives who could not unreservedly be regarded as normal in respect of reproduction. But perhaps the most serious objection to most previous investigations has been failure to take full account of the influence of maternal age: most mothers of mongols are in the older age groups where the expected incidence of reproductive abnormalities is obviously raised. Unless a correction is introduced by standardization, or by the use of an age-matched control group, the frequency of abnormalities which become more common at late ages will inevitably appear to be raised. Jenkins (1933) is one of the few investigators who appear to have recognized this difficulty. 
The present series is perhaps not large enough to permit firm conclusions concerning the aetiological significance of the variables examined (fertility, menstrual history, abortion rates, bleeding during pregnancy, and gynaecological disorders). The results suggest that some differences between mothers of affected and controls might emerge from a larger series: the fallow period preceding the birth of a mongol may be prolonged; habitual abortion may be more common; bleeding during pregnancy may occur more frequently. But if such differences exist, it seems unlikely that they will be large. The present investigation provides no evidence of any other abnormality in the reproductive history of mothers of mongols.

\section{SUMMARY}

(1) The reproductive histories of 217 Birmingham women who gave birth to a mongol in the period 1942-52 were compared with those of a control group of 139 women who produced unaffected infants during the same period. The two groups differed slightly with respect to age at birth of propositus; variation from this source was removed by standardization.

(2) The two groups showed little difference in fertility as measured by the number of conceptions preceding propositi, pregnancy-free- intervals immediately before propositi and before prior sibs, number of conceptions following propositi, and pregnancy-free intervals between the birth of the propositus and the next conception.

(3) Mothers of mongols did not differ significantly from controls in respect of age at menarche, length of menstrual cycle, age at onset of the meno- pause, and uterine bleeding during the related pregnancy.

(4) Abortion rates were higher for mothers of mongols than for controls. This was due largely to the presence of a few women in the mongol group who experienced repeated abortions. Abortions were not unduly common in pregnancies immediately before or after that of the propositus.

(5) Gynaecological disorders were reported with equal frequency in the two groups.

For permission to examine records we are indebted to the staffs of Birmingham hospitals and to the Birmingham Maternity and Child Welfare and Mental Health Departments. Observations were recorded in the homes of cases by Miss Mary Gradwell and Miss Eileen Gibson.

\section{REFERENCES}

Beidleman, B. (1945). Amer. J. ment. Defic, 50, 35.

Benda, C. E. (1946). "Mongolism and Cretinism." Grune and Stratton, New York.

(1949). J. Amer. med. Ass., 139, 979.

99, 822.

Bleyer, A. (1938). Amer. J. Dis. Child., 55, 79.

Brousseau, K. (1928). "Mongolism. A Study of the Physical and Mental Characteristics of Mongolian Imbeciles." Baillière, Tindall and Cox, London.

Down, J. Langdon (1909). Brit. med. J., 2, 665.

Doxiades, L., and Portius, W. (1938). Z.menschl. Vererb. - u. KonstitLehre, 21, 384.

Engler, M. (1949). “Mongolism (Peristatic Amentia).” Wright, Bristol. Geyer, H. (1937). Erbarzt, 4, 115.

Ingalls, T. H. (1947). Amer. J. Dis. Child., 74, 147.

Jenkins, R. L. (1933). Ibid., 45, 506.

Murphy, M. (1936). Hum. Biol., 8, 256.

Øster, J. (1953). "Mongolism. A Clinicogenealogical Investigation comprising 526 Mongols living on Seeland and Neighbouring Islands in Denmark." Danish Science Press Copenhagen.

Islands in Denmark." Danish Science Press, Cope
Penrose, L. S. (1934). Proc. roy. Soc. B., 115, 431.

(1949). "The Biology of Mental Defect." Sidgwick and Jackson London.

Record, R. G., and McKeown, T. (1950). British Journal of Social Medicine, 4, 26.

and Smith, A. (1955), British Journal of Preventive and Social Medicine, 9, 10.

Schröder, H. (1938). Z. ges. Neurol. Phsychiat., 163, 390.

Shuttleworth G. E. (1909). Brit. med. J., 2, 661.

Smith, A., and Record, R. G. (1955). British Journal of Preventive and Social Medicine, 9, 51. 